\title{
Minimal access excision of aortic valve fibroelastoma: a case report and review of the literature
}

\author{
Leanne Harling ${ }^{1 *}$, Thanos Athanasiou', Hutan Ashrafian', John Kokotsakis', Virginia Brown ${ }^{1}$, Anthony Nathan ${ }^{2}$ \\ and Roberto Casula ${ }^{1}$
}

\begin{abstract}
Papillary fibroelastomas are rare primary tumours of cardiac origin accounting for approximately $10 \%$ of all primary cardiac neoplasms. Due to a high thromboembolic risk, surgical excision is the mainstay of treatment in these patients and median sternotomy the most widely used approach. We describe the case of a 43 year-old lady presenting with acute myocardial infarction secondary to aortic valve papillary fibroelastoma subsequently excised using a minimal access technique. From our experience mini-sternotomy offers excellent exposure and allows for safe resection in such cases, improving cosmesis without compromising either intra or post-operative outcome.
\end{abstract}

Keywords: Fibroelastoma, Minimally invasive, Aortic valve

\section{Background}

Papillary fibroelastomas (PFE) are rare primary tumours of cardiac origin accounting for approximately $10 \%$ of all primary cardiac neoplasms [1]. They may occur anywhere on the endocardium, although are more common in the left heart and display a predilection for valvular structures. The aortic valve is the most commonly affected, with a number of such tumours arising from the non-coronary leaflet $[2,3]$. Whilst the majority are incidental findings on echocardiography, symptoms most commonly occur subsequent to embolisation, and may give rise to a wide variety of presenting features including neurological events (transient ischaemic attack, stroke, amaurosis fugax, spinal cord infarction) [4-6], acute coronary syndrome [7,8], and distal thromboembolism [9]. More rarely, cardiac conduction abnormalities, direct coronary ostial occlusion and outflow tract obstruction (in ventricular PFE) have been reported [10,11].

Macroscopically, papillary fibroelastomas are characterised by multiple frond-like fibrous projections creating a 'sea anemone' appearance when immersed in saline.

\footnotetext{
* Correspondence: leanne.harling@imperial.ac.uk

'Department of Surgery and Cancer, Imperial College Healthcare NHS Trust, Imperial College London, 10th Floor, QEQM Building, St. Mary's Campus, Praed Street, London W2 1NY, UK

Full list of author information is available at the end of the article
}

Histologically, the tumour is comprised of an avascular fibroelastic core, made up of a hyalinised collagen matrix with a rim of smooth muscle cells and elastic fibres, lined by endocardial endothelium $[12,13]$. Immunohistochemical characteristics include positive staining for factor VIIIrelated antigen, CD34 and Vimentin confirming a vascular endothelial cell lining, and multilayered type IV collagen elastic proliferation deep to the surface membrane [14].

The aetiology of PFE remains largely unknown [3]. Recent hypotheses include fibroblast infiltration with organisation of mural thrombi [15], viral induced tumour growth [13], and an endothelial response to cardiac surgery, mechanical trauma or thoracic radiation $[16,17]$. Historically, PFE has also been described as both a true neoplasm and a hamartomatous lesion [18], whereas some authors have suggested they are merely an overgrowth of Lambl's excrescences [19].

Over recent years, there has been an increase in the number of reports of minimally invasive, thoracoscopic and even robotic resections of aortic valve PFE (Table 1) [20-25]. A total of 9 cases have been reported to date, of which 7 describe PFE of the AV (5 non-coronary leaflet, 2 right coronary leaflet), 1 of the right atrium and 1 of the left ventricle. Both mini-sternotomy and mini-thoracotomy approaches ( \pm thoracoscopic assistance) have been used with incision size ranging from 4 to $9 \mathrm{~cm}$, although it seems that mini- 
Table 1 Summary of published results

\begin{tabular}{|c|c|c|c|c|c|c|c|c|c|c|c|c|}
\hline Reference & $\mathrm{n}$ & $\begin{array}{l}\text { Age } \\
\text { (yrs) }\end{array}$ & M:F & Presentation & Site of lesion & $\begin{array}{l}\text { Size of lesion } \\
(\mathrm{cm})\end{array}$ & Access Route & $\begin{array}{l}\text { Temp } \\
\left({ }^{\circ} \mathrm{C}\right)\end{array}$ & $\begin{array}{l}\text { CPB Time } \\
\text { (mins) }\end{array}$ & $\begin{array}{l}\text { X-Clamp } \\
\text { Time } \\
\text { (mins) }\end{array}$ & Outcome & $\begin{array}{l}\text { Follow-up } \\
\text { (Months) }\end{array}$ \\
\hline Zebele 2010 [25] & 1 & - & $0: 1$ & Not described & $\begin{array}{l}\text { Non-coronary } \\
\text { leaflet }\end{array}$ & $1.0 \times 1.0$ & $\begin{array}{l}7 \mathrm{~cm} \text { skin incision with } \\
\text { mini-sternotomy }\end{array}$ & - & - & - & Not described & - \\
\hline Hsu 2006 [21] & 4 & $54 \pm 5$ & $0: 4$ & $\begin{array}{l}2 \text { Embolic stroke, } \\
1 \text { sequential TIAs, } \\
\text { and } 1 \text { SOBOE \& } \\
\text { lightheadedness }\end{array}$ & $\begin{array}{l}3 \text { Non coronary } \\
\text { leaflet } 1 \text { R coronary } \\
\text { cusp }\end{array}$ & $0.8 \pm 0.3 \times 0.65 \pm 0.35$ & $\begin{array}{l}\text { Partial sternotomy } \\
\text { extended into 3rd ICS. } \\
\text { Incision length } 6.1 \pm 1.4 \mathrm{~cm}\end{array}$ & & $66 \pm 7.5$ & $34.5 \pm 3$ & $\begin{array}{l}\text { LOS } 4 \pm 0.5 \text { days } \\
\text { No complications } \\
\text { until point of } \\
\text { discharge }\end{array}$ & - \\
\hline \multirow[t]{2}{*}{ Je 2008 [22] } & \multirow[t]{2}{*}{1} & \multirow[t]{2}{*}{39} & \multirow[t]{2}{*}{ 1:0 } & \multirow{2}{*}{$\begin{array}{l}\text { Asymptomatic. } \\
\text { Incidental finding on } \\
\text { investigation for } \\
\text { hypertrophic } \\
\text { cardiomyopathy }\end{array}$} & \multirow{2}{*}{$\begin{array}{l}\text { Medial side of } \\
\text { antero-lateral } \\
\text { papillary muscle } \\
\text { of the LV }\end{array}$} & \multirow[t]{2}{*}{$1.5 \times 1.0$} & $\begin{array}{l}5 \mathrm{~cm} \text { R anterior } \\
\text { thoracotomy (camera } \\
\text { control: AESOP 3000) }\end{array}$ & \multirow[t]{2}{*}{-} & \multirow[t]{2}{*}{57} & \multirow[t]{2}{*}{24} & \multirow[t]{2}{*}{$\begin{array}{l}\text { Uneventful recovery. } \\
\text { Follow up echo no } \\
\text { residual mass, } \\
\text { normal MV }\end{array}$} & \multirow[t]{2}{*}{-} \\
\hline & & & & & & & $\begin{array}{l}\text { Cannulation: RCFA, RCFV } \\
\text { and RIJV. }\end{array}$ & & & & & \\
\hline \multirow[t]{2}{*}{ Grande 2007 [20] } & \multirow[t]{2}{*}{1} & \multirow[t]{2}{*}{22} & \multirow[t]{2}{*}{ 1:0 } & \multirow[t]{2}{*}{$\begin{array}{l}\text { Asymptomatic. } \\
\text { Incidental finding on } \\
\text { TTE for MV prolapse }\end{array}$} & \multirow[t]{2}{*}{$\begin{array}{l}\text { Ventricular aspect } \\
\text { of } \mathrm{R} \text { coronary leaflet }\end{array}$} & $0.6 \times 0.9$ & $\begin{array}{l}9 \mathrm{~cm} \text { 'J' incision on } \\
\text { midline from } 3 \mathrm{~cm} \text { below } \\
\text { jugular notch to } 2^{\text {nd }} \mathrm{ICS} \text {. } \\
\text { Sternum opened from } \\
\text { manubrium to } 3 \mathrm{rd} \text { ICS. }\end{array}$ & \multirow[t]{2}{*}{-} & \multirow[t]{2}{*}{-} & \multirow[t]{2}{*}{50} & \multirow[t]{2}{*}{$\begin{array}{l}\text { Discharge day } 5 . \\
\text { No complications at } \\
\text { last follow up. }\end{array}$} & \multirow[t]{2}{*}{6} \\
\hline & & & & & & & $\begin{array}{l}\text { Cannulation: Aorta, Right } \\
\text { atrial appendage. }\end{array}$ & & & & & \\
\hline \multirow[t]{3}{*}{ Woo 2005 [24] } & \multirow[t]{3}{*}{1} & \multirow[t]{3}{*}{50} & \multirow[t]{3}{*}{ 1:0 } & \multirow{3}{*}{$\begin{array}{l}\text { Asymptomatic, } \\
\text { surveillance revealed } \\
\text { non-specific T wave } \\
\text { changes. TTE finding } \\
\text { of PFE }\end{array}$} & \multirow[t]{3}{*}{$\begin{array}{l}\text { Non-coronary } \\
\text { leaflet }\end{array}$} & \multirow[t]{3}{*}{ Diameter 1.0} & $\begin{array}{l}\text { Robotic: } 5 \mathrm{~cm} \text { right anterior } \\
\text { mini-thoracotomy } 2 \text { nd ICS. }\end{array}$ & \multirow[t]{3}{*}{30} & \multirow[t]{3}{*}{-} & \multirow[t]{3}{*}{48} & \multirow{3}{*}{$\begin{array}{l}\text { Discharge day } 3 . \\
\text { No complications } \\
\text { at last follow up. }\end{array}$} & \multirow[t]{3}{*}{1} \\
\hline & & & & & & & $\begin{array}{l}\text { Robotic arms via stab } \\
\text { incisions R 1st and 3rd ICS }\end{array}$ & & & & & \\
\hline & & & & & & & Cannulation: RCFA, RCFV & & & & & \\
\hline \multirow[t]{2}{*}{ Kim 2007 [23] } & \multirow[t]{2}{*}{1} & 62 & $1: 0$ & $\begin{array}{l}\text { Asymptomatic, } \\
\text { surveillance CT } \\
\text { following total }\end{array}$ & Right Atrium & - & $\begin{array}{l}4 \mathrm{~cm} \mathrm{R} \text { anterior } \\
\text { mini-thoracotomy } \\
\text { in 4th ICS }\end{array}$ & - & 24 & - & $\begin{array}{l}\text { Discharge day } 4 . \\
\text { No complications } \\
\text { until point of }\end{array}$ & - \\
\hline & & & & & & & Cannulation: RCFA, RCFV & & & & & \\
\hline
\end{tabular}

TIA - Transient Ischaemic Attack; SOBOE - Shortness of Breath on Exertion; TTE - Trans Thoracic Echo; MV - Mitral Valve; LV - Left Ventricle; CT - Computerised Tomography; RCFA - Right Common Femoral Artery; RCFV - Right Common Femoral Vein; RIJV - Right Internal Jugular Vein; ICS - Inter-costal Space; LOS - length of Stay; CPB - Cardiopulmonary Bypass. 


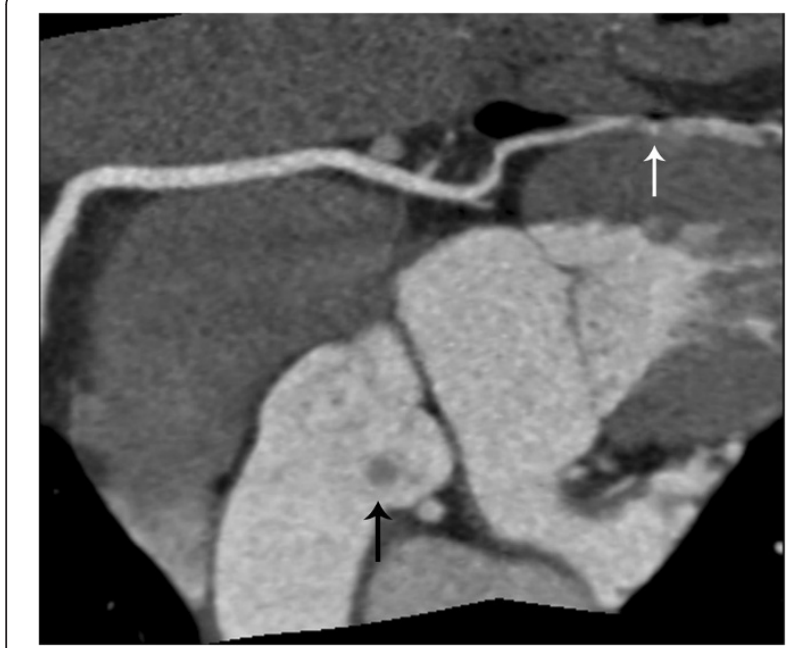

Figure 1 Computerised Tomography image demonstrating both an aortic valve lesion (black arrow) and an embolus to the distal left anterior descending artery (white arrow).

sternotomy offers improved intra-operative exposure, reduced post-operative pain and less mammary scaring when compared to mini-thoracotomy in cases of AV PFE [26]. Whilst no long term follow up has been documented, short term results with such procedures are encouraging with a mean hospital stay of $4 \pm 0.57$ days and no adverse events reported prior to discharge.

In this report we review the current literature on minimally invasive intervention for PFE and present a case of aortic valve PFE resected via mini-sternotomy.

\section{Case report}

A 43-year-old lady without significant co-morbidity and no apparent cardiovascular risk factors presented to us for a second opinion following an emergent admission to her local hospital department with sudden onset

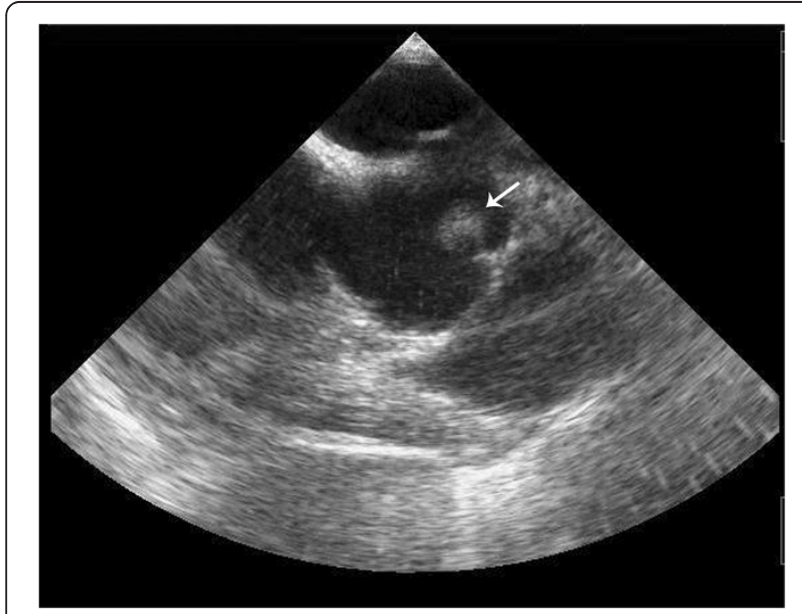

Figure 2 Trans-thoracic echocardiography demonstrating mobile mass on the left coronary cusp of the aortic valve.

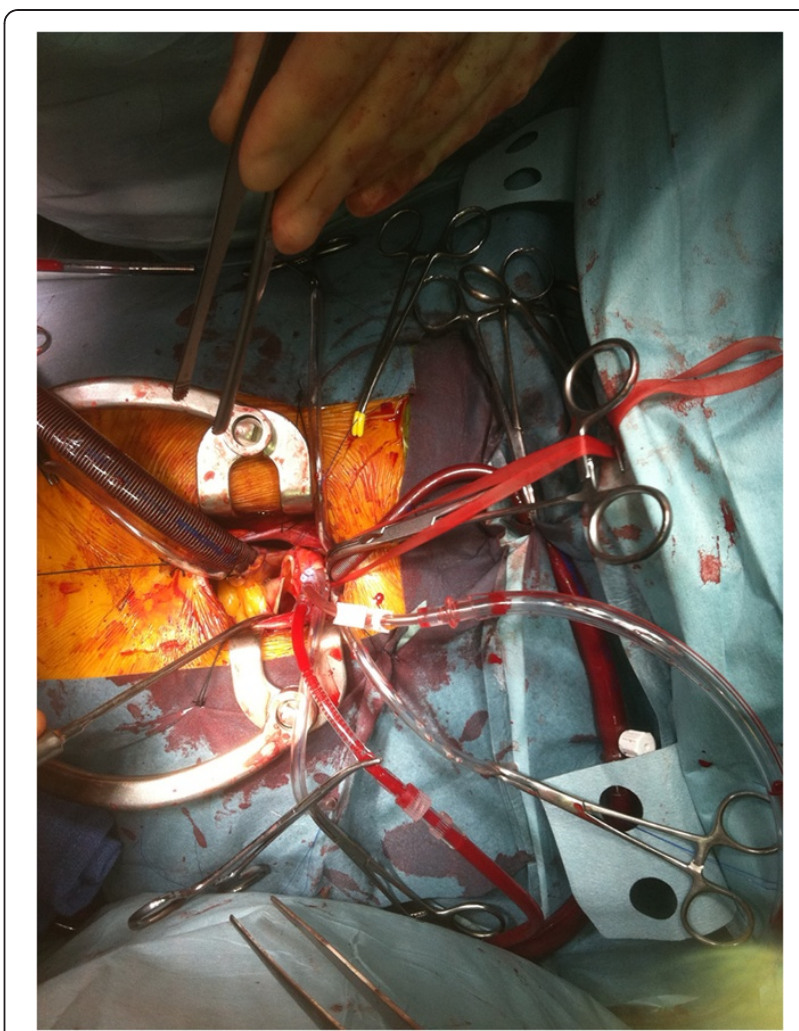

Figure 3 Minimal access approach and set-up.

central chest pain and ECG changes indicative of acute anterior myocardial infarction (AMI). After initial supportive medical therapy and improvement of her acute symptoms, investigations to further characterise the nature of her coronary disease were performed. CT coronary angiography showed the culprit lesion was likely to be an embolic occlusion of the distal left anterior descending (LAD) artery after the second diagonal branch, but incidentally made note of a soft tissue mass seen on

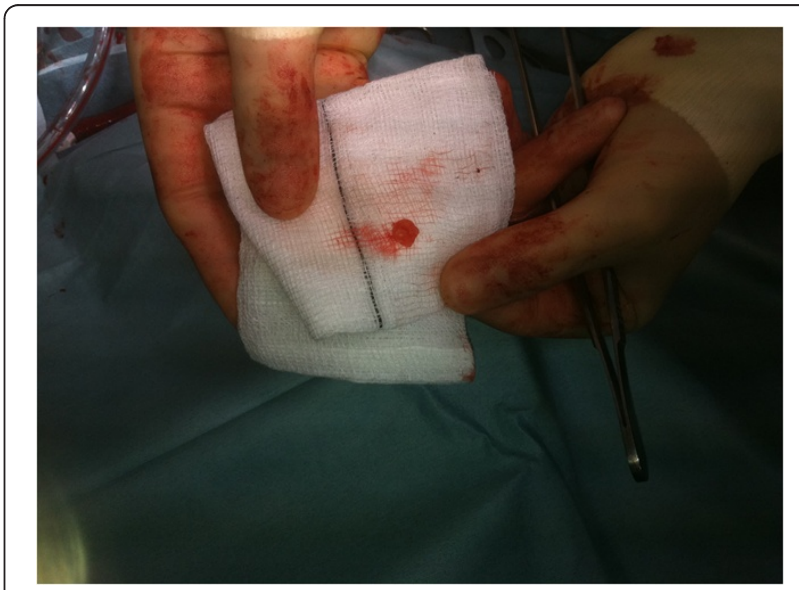

Figure 4 Excised fibroelastoma. 


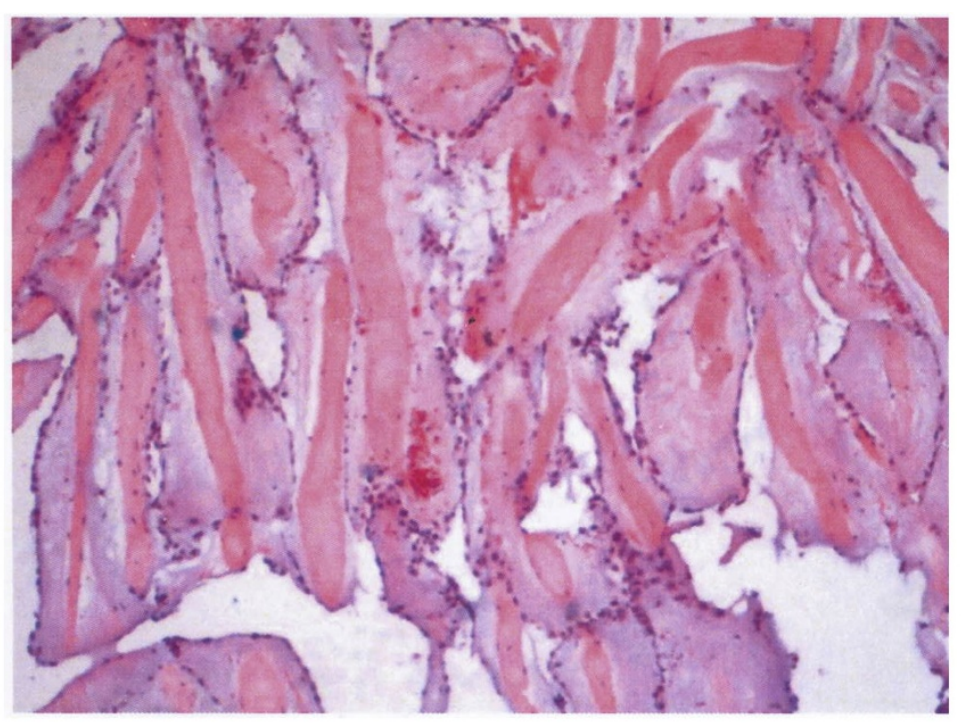

A: Haematoxylin-Eosin staining demonstrating papillary fronds with central collagen matrix lined with endothelial cells

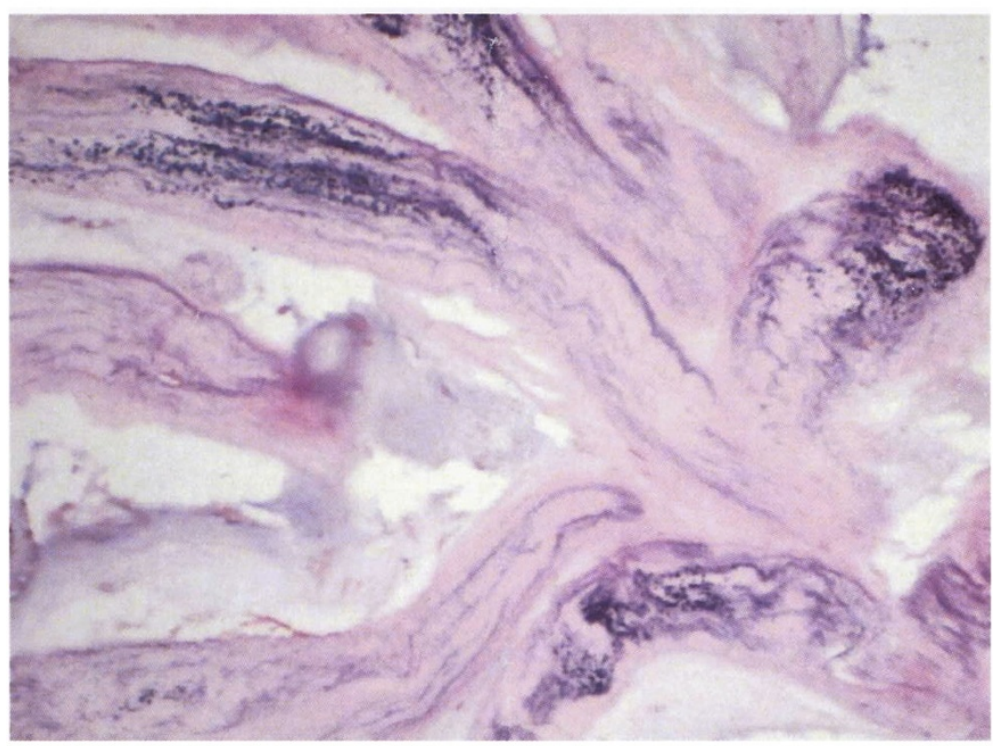

B: Verhoff-Van Gieson stain demonstrating multiple elastic layers

Figure 5 Histology of the excised PFE.

the left coronary cusp of the aortic valve (AV) (Figure 1). Further characterisation of this lesion by both transthoracic (TTE) (Figure 2) and trans-oesophageal echo (TOE) showed appearances consistent with a papillary fibroelastoma (PFE) and she was admitted for surgery on the 24th October 2011. A minimal access $6 \mathrm{~cm}$ skin incision was made, and the chest entered via a limited upper sternotomy extending to the right 3rd intercostal space. Cannnulation was performed via the ascending aorta and right atrium (Figure 3). Following transverse aortotomy, the aortic valve was inspected revealing a round mass at the very edge of the left coronary cusp. The lesion was excised, sparing the $\mathrm{AV}$, and the valve tested confirming perfect competence prior to closure. Total cross clamp time was 16 minutes with an uneventful wean from bypass. Prior to decannulation, intra-operative TOE confirmed normal valve competence and good overall myocardial function. Total operative time was 52 minutes. The excised lesion measured $9 \times 8 \times 3 \mathrm{~mm}$ (Figure 4). Histopathology demonstrated a 
fronded papillary lesion, with cores of collagen surrounded by elastic tissue covered with a layer of endocardial endothelium, typical of PFE (Figure 5). The patient had an uneventful post-operative course and was discharged home 3 days after surgery.

\section{Conclusions}

The high risk of thromboembolic complications makes urgent surgical intervention a requirement in the majority of PFEs. Whilst symptomatic patients presenting with non-mobile lesions may be treated with long-term anticoagulation and regular follow up, there is little data reporting outcomes in such patients [3]. Median sternotomy is still the most widely used approach, however, in the absence of other pathology requiring open cardiac surgical intervention, there is increasing evidence that minimally invasive techniques offer excellent exposure and allow for safe resection, particularly in aortic PFEs.

Minimally invasive surgery boasts a number of potential advantages including improved cosmesis, a reduction in post-operative pain, blood loss, subsequent transfusion and shorter intensive care unit and overall hospital stay [27]. Consequently, such techniques may not only lead to greater overall patient satisfaction but also improve hospital resource utilisation. Conversely however, minimally invasive surgery is associated with a steep operator learning curve and, in the case of surgical robotics, the need for costly equipment may limit its uptake in smaller centres. Furthermore, evidence on the optimal surgical approach to PFE also remains limited, and it is unlikely that a randomized controlled trial may ever be performed in light of the low incidence of these tumours.

Our case demonstrates the safe application of a minimally invasive approach to aortic valve papillary fibroelastoma without compromising cross clamp or operative time and achieving an excellent early clinical result. We also present increasing evidence to support the use of minimally invasive approaches in the treatment of PFE, particularly in the aortic position. We feel that in selected patients with PFE minimally invasive surgery should be the approach of choice, and where this is not available, we advocate prompt referral to a specialist centre with the provision and expertise to undertake a minimal access approach.

\section{Consent}

Written informed consent was obtained from the patient for publication of this case report and any accompanying images. A copy of the written consent is available for review by the Editor-in-Chief of this journal.

\footnotetext{
Abbreviations

PFE: Papillary fibroelastoma; CT: Computerised tomography; ECG: Electrocardiograph; AMI: Acute mycocardial infarction; TOE: Transoespohageal echocardiography; TTE: Trans-thoracic echocardiography.
}

\section{Competing interests}

There are no financial or non-financial competing interests.

\section{Author contributions}

RC and TA carried out the surgical procedure, participated in provision of clinical information and reviewed the manuscript. VB provided anaesthetic support and trans-oesophageal echo in this case. AN consulted with the patient and provided cardiology care. LH, HA and JK performed the literature review and drafted the manuscript. All authors read and approved the final manuscript.

\section{Acknowledgements}

We would like to thank both our histopathology and radiology departments for providing the specimens and images shown.

\section{Author details}

${ }^{1}$ Department of Surgery and Cancer, Imperial College Healthcare NHS Trust, Imperial College London, 10th Floor, QEQM Building, St. Mary's Campus, Praed Street, London W2 1NY, UK. ²Department of Cardiology, Watford General Hospital, Vicarage Road, Herts, Watford WD18 OHB, Ireland.

Received: 16 April 2012 Accepted: 21 August 2012

Published: 3 September 2012

\section{References}

1. Reynen K: Frequency of primary tumors of the heart. Am J Cardiol 1996, 77(1):107.

2. Ngaage DL, Mullany CJ, Daly RC, Dearani JA, Edwards WD, Tazelaar HD, McGregor CG, Orszulak TA, Puga FJ, Schaff HV, Sundt TM 3rd, Zehr KJ: Surgical treatment of cardiac papillary fibroelastoma: a single center experience with eighty-eight patients. Ann Thorac Surg 2005, 80(5):1712-1718.

3. Gowda RM, Khan IA, Nair CK, Mehta NJ, Vasavada BC, Sacchi TJ: Cardiac papillary fibroelastoma: a comprehensive analysis of 725 cases. Am Heart J 2003, 146(3):404-410.

4. Alawi A, Kassabian EB, Ashoush R, Jebara VA: Aortic valve papillary fibroelastoma. Cardiovasc Surg 2002, 10(1):65-67.

5. Lopez-Sanchez E, Munoz EF, Avino Martinez JA, Menezo Rozalen JL: Central retinal artery occlusion as the initial sign of aortic valve papillary fibroelastoma. Am J Ophthalmol 2001, 131(5):667-669.

6. Pello SJ, Ashkenazi A: Spinal cord infarction in a woman with cardiac fibroelastoma. Neurologist. [Case Reports] 2011, 17(1):47-48.

7. Alozie A, Prall F, Hendrikson C, Westphal B, Werner D: Embolization of multiple papillary fibroelastoma of the aortic valve as cause of a STsegment elevation myocardial infarction. Eur J Echocardiogr 2011, 12(11):817.

8. Bruno VD, Mariscalco G, De Vita S, Piffaretti G, Nassiacos D, Sala A: Aortic valve papillary fibroelastoma: a rare cause of angina. Tex Heart Inst J 2011, 38(4):456-457.

9. Gilbert P, Bourgault C, Couture C, Dery JP, Bergeron S, Senechal M: Splenic infarction associated with a mobile aortic valve lesion: a case report and review of the literature. Can J Cardiol 2009, 25(6):e215-e216.

10. Butz T, Meissner A, Plehn G, Raute-Kreinsen U, Gummert J, Trappe HJ: Papillary fibroelastoma prolapsing into the left ventricular outflow tract: diagnosis using three-dimensional TEE. Herz 2010, 35(7):503-505.

11. Erdoes G, Stalder M, Basciani R, Gugger M, Carrel T, Eberle B: An uncommon cause of coronary artery ostial obstruction: papillary fibroelastoma. Echocardiography 2010, 27(3):337-340.

12. de Visser RN, van Mieghem C, van Pelt NC, Weustink AC, Kerker JP, Galema TW: Papillary fibroelastoma of the aortic valve and coronary artery disease visualized by 64-slice CT. Nat Clin Pract Cardiovasc Med 2008, 5(6):350-353.

13. Grandmougin D, Fayad G, Moukassa D, Decoene C, Abolmaali K, Bodart JC, Limousin M, Warembourg H: Cardiac valve papillary fibroelastomas: clinical, histological and immunohistochemical studies and a physiopathogenic hypothesis. J Heart valve Dis 2000, 9(6):832-841.

14. Rubin MA, Snell JA, Tazelaar HD, Lack EE, Austenfeld JL, Azumi N: Cardiac papillary fibroelastoma: an immunohistochemical investigation and unusual clinical manifestations. Mod Pathol 1995, 8(4):402-407.

15. Salyer WR, Page DL, Hutchins GM: The development of cardiac myxomas and papillary endocardial lesions from mural thrombus. Am Heart J 1975, 89(1):4-17. 
16. Kurup AN, Tazelaar HD, Edwards WD, Burke AP, Virmani R, Klarich KW, Orszulak TA: latrogenic cardiac papillary fibroelastoma: a study of 12 cases (1990 to 2000). Hum Pathol 2002, 33(12):1165-1169.

17. Shahian DM, Labib SB, Chang G: Cardiac papillary fibroelastoma. Ann Thorac Surg 1995, 59(2):538-541.

18. Raeburn C: Papillary fibro-elastic hamartomas of the heart valves. J Pathol Bacteriol 1953, 65(2):371-373.

19. Heath D, Best PV, Davis BT: Papilliferous tumours of the heart valves. $\mathrm{Br}$ Heart J 1961, 23:20-24.

20. Grande AM, Massetti M, Castiglione N, Vigano M: Valve-sparing removal of aortic fibroelastoma through ministernotomy. J Heart Valve Dis [Case Reports] 2007, 16(2):206-208.

21. Hsu VM, Atluri P, Keane MG, Woo YJ: Minimally invasive aortic valve papillary fibroelastoma resection. Interact Cardiovasc Thorac Surg 2006, 5(6):779-781.

22. Je HG, Kim YS, Jung SH, Lee JW: Resection of left ventricular papillary fibroelastoma through thoracoscopic-assisted minithoracotomy. Interact Cardiovasc Thorac Surg. [Case Reports] 2008, 7(2):320-321.

23. Kim RW, Jeffery ME, Smith MJ, Wilensky RL, Woo EY, Woo YJ: Minimally invasive resection of papillary fibroelastoma in a high-risk patient. J Cardiovasc Med (Hagerstown) 2007, 8(8):639-641.

24. Woo YJ, Grand TJ, Weiss SJ: Robotic resection of an aortic valve papillary fibroelastoma. Ann Thorac Surg [Case Reports] 2005, 80(3):1100-1102.

25. Zebele C, Tan ME, Hamad MA: Excision of noncoronary aortic cusp fibroelastoma via ministernotomy. Asian Cardiovasc Thorac Ann [Case Reports] 2010, 18(6):596-597.

26. Wang WL, Cai KC, Zeng WS, Jiang RC: Experience in using three different minimally invasive approaches in cardiac operations. Med Sci Monit 2003, 9(3):CR109-CR113.

27. Khoshbin E, Prayaga S, Kinsella J, Sutherland FW: Mini-sternotomy for aortic valve replacement reduces the length of stay in the cardiac intensive care unit: meta-analysis of randomised controlled trials. BMJ Open 2011, 1(2):e000266.

doi:10.1186/1749-8090-7-80

Cite this article as: Harling et al: Minimal access excision of aortic valve fibroelastoma: a case report and review of the literature. Journal of Cardiothoracic Surgery 2012 7:80

\section{Submit your next manuscript to BioMed Central and take full advantage of:}

- Convenient online submission

- Thorough peer review

- No space constraints or color figure charges

- Immediate publication on acceptance

- Inclusion in PubMed, CAS, Scopus and Google Scholar

- Research which is freely available for redistribution 